\title{
TWO NEW SPECIES AND NEW RECORDS OF PLATYSTELE (PLEUROTHALLIDINAE: ORCHIDACEAE) FROM LOS CEDROS RESERVE IN ECUADOR
}

\author{
Luis E. Baquero R..$^{1-3} \&$ Denisse Galarza Verkovitch ${ }^{2}$
}

${ }^{1}$ Carrera de Ingeniería Agroindustrial y Alimentos. Facultad de Ingeniería y Ciencias Agropecuarias. Universidad de Las Américas, Calle José Queri, Quito 170137, Pichincha, Ecuador 2 Jardín Botánico de Quito, Pasaje \#34, Rumipampa E6-264 y Av Shyris, Interior Parque La Carolina, Quito, 170135, Pichincha, Ecuador

${ }^{3}$ Author for correspondence: lbaquero@hotmail.com

\begin{abstract}
Two new species of Platystele were discovered at the orchid-rich forest of Los Cedros Reserve at North-west Ecuador. Many species of orchids grow in these forests and some endemic to it. Platystele cedriensis is similar to $P$. rhinocera from which it differs in the horizontal to descending inflorescence and the three-veined dorsal sepal. Platystele decouxii presents flowers with a unique heart-shaped lip with a heart-shape depression in the blade of the lip. We warn that on-going mining activities and concessions put in risk these and other endemic species from Los Cedros Reserve.

Resumen: Dos nuevas especies de Platystele fueron descubiertas en el bosque altamente rico en especies de orquídeas de la Reserva Los Cedros al noroeste de Ecuador. Muchas especies de orquídeas crecen en estos bosques y algunas son endémicas de este sitio. Platystele cedriensis es similar a $P$. rhinocera de la que se diferencia por inflorescencias horizontales a descendentes y el sépalo dorsal con tres nervaduras. Platystele decouxii presenta flores con un labelo único en el género en forma de corazón al igual que la depresión en el mismo, también en forma de corazón. Aquí advertimos sobre los riesgos de las actividades mineras que se llevan a cabo y las concesiones que ponen en peligro estas y otras especies de la Reserva Los Cedros.
\end{abstract}

Key words / Palabras clave: Carchi, especies simpátricas, Orchidaceae, Platystele cedriensis, Platystele decouxii, sympatric species

Introduction. Los Cedros reserve is one of the biggest private protected areas of western Andean cloud forests in Ecuador, and has been extensively explored for orchids. The Reserve covers more than 5,000 hectares of cloud forest, ranging from 980 to 2200 meters in elevation. There are currently 186 species of orchids known to Los Cedros, 106 of which are unique to the Reserve (Jørgensen \& León-Yánez 1999, Roy et al. 2018).

In the 1990s Stig Dalström and colleagues discovered many new species of orchids in Los Cedros Reserve. Some of these discoveries included species such as Trisetella dalstroemii Luer, Dracula morleyi Luer \& Dalström (both endemic to Los Cedros Reserve), and Dracula lafleurii Luer \& Dalström, among other species (Luer 1993, 1994, Dodson 2003, Dodson 2004). Lorena Endara also did research in Los Cedros Reserve, among her discoveries are Porroglossum lorenae Luer and Platystele gaileana Luer \& Endara, the latter representing the only endemic Platystele (Pleurothallidinae) reported for Los Cedros until now (Luer 2004).

In 2017 a group of researchers from Quito Botanical Garden and the Universidad de Las Américas visited Los Cedros Reserve in search of new species of orchids and novel records of this family of plants for the reserve. Here we report on the findings of this expedition, describing two new species of Platystele, and reporting three additional species previously unknown for the Reserve. 


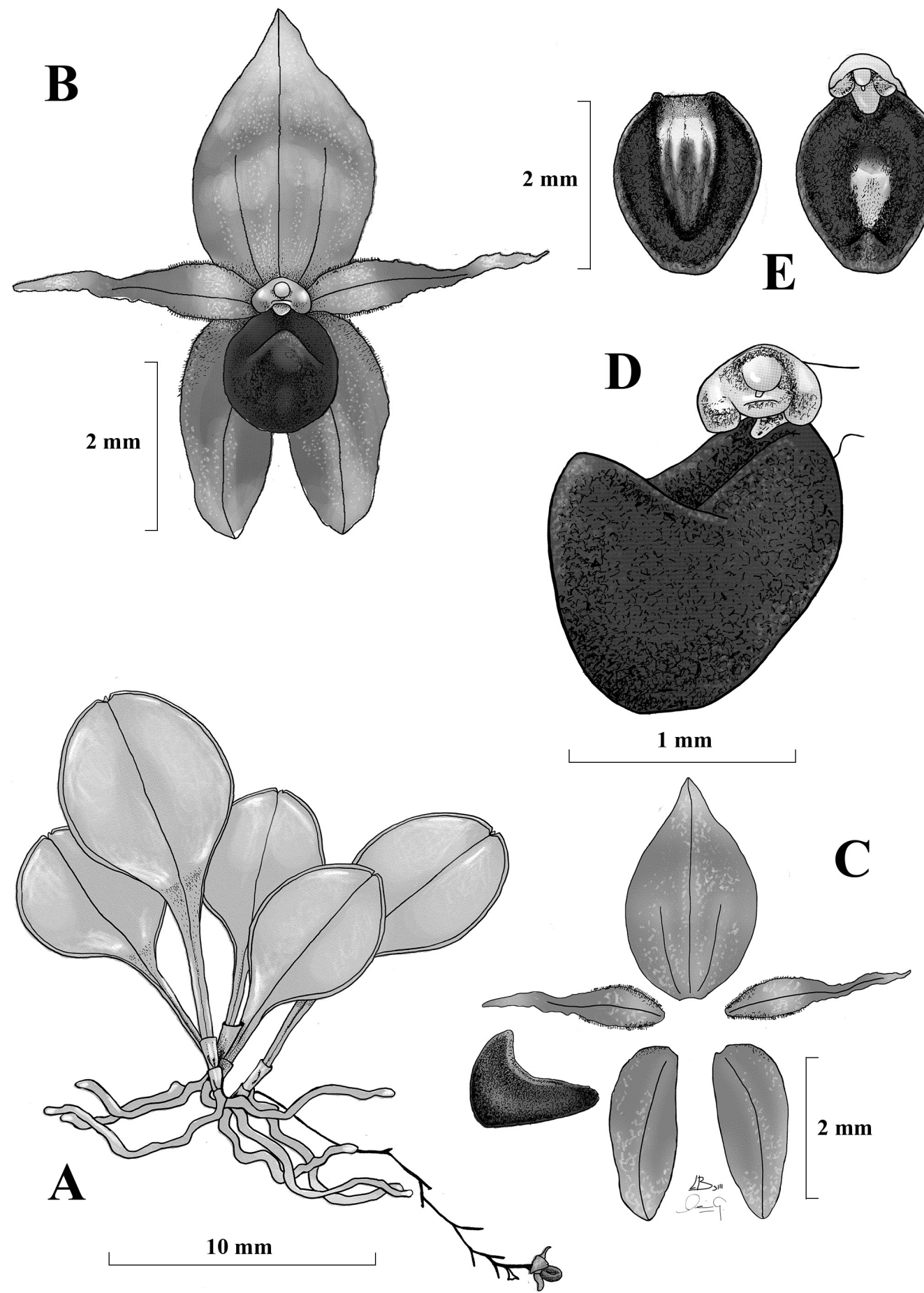

Figure 1. Platystele cedriensis Baquero \& G.Verkovitch. A. Habit. B. Frontal view of the flower. C. Disected perianth. D. View of column and lip. E. Top and bottom view of the lip. Drawing by Denisse Galarza-Verkovitch and Luis E. Baquero from holotype. 


\section{TAXONOMIC TREATMENT}

Platystele cedriensis Baquero \& G.Verkovitch, sp. nov.

TYPE: Ecuador. Imbabura, "Los Cedros" Reserve, $0^{\circ} 18^{\prime} 35.62^{\prime \prime} \mathrm{N}, 78^{\circ} 46^{\prime} 47.01^{\prime \prime} \mathrm{W}, 1500 \mathrm{~m}, 5 / 11 / 2017$, Luis Baquero 3110 (Holotype, QCNE). Figs. 1, 3-4.

Diagnosis: Platystele cedriensis is similar to $P$. rhinocera, from which it differs on the horizontal to descending inflorescence versus the erect inflorescence in P. rhinocera. Also, the dorsal sepal of $P$. cedriensis is three-veined whereas the dorsal sepal of $P$. rhinocera is one-veined. The shortly glandular sepals and shortly pubescent petals in P. cedriensis and the protruding apex of the lip, bent in a $90^{\circ}$ angle (Fig. 4C), are different from the glabrous sepals and petals with cellular margins and the abruptly incurved apex of the lip in P. rhinocera.

Plant small, epiphytic, densely caespitose, erect, up to $30 \mathrm{~mm}$ tall. Roots basal, slender, to $0.5 \mathrm{~mm}$ in diameter. Ramicauls terete, very short enclosed by two or three ribbed, imbricating sheaths up to $2 \mathrm{~mm}$ long. Leaf erect, coriaceous, petiolate-spatulate, roundish, $7-10 \mathrm{~mm}$ long, including a petiole $5-12 \mathrm{~mm}$ long, conduplicate, two ribs parallel and close to the entire margine of the blade, retuse apex, with an apiculus nested inside the leaf, 2.0-2.8 $\mathrm{mm}$ wide. Inflorescence loose, horizontal to descending, cylindrical, flexuous, distichous, successively several-flowered raceme, raceme up to $25 \mathrm{~mm}$ long; borne by a slender $(0.2$ $\mathrm{mm}$ in width) peduncle $5-10 \mathrm{~mm}$ long arising laterally from the ramicaul; floral bracts thin, acute, conduplicate, to $0.8 \mathrm{~mm}$ long; pedicels $1.7-2.0 \times 0.25$ $\mathrm{mm}$, thicker than the peduncle. Ovary three ridged, short, to $0.8 \times 0.65 \mathrm{~mm}$. Sepals translucent yellowishgreen suffused with rosy-purple, at the adaxial side, towards the base, shortly glandular; dorsal sepal three veined, central vein complete, lateral veins incomplete, broadly elliptical and concave, $2.2 \times$ $1.5 \mathrm{~mm}$, with an acuminate apex; lateral sepals free, slightly convex, one veined, unequal-sided, oblique, oblong to elliptical with and an acute, reflexed apex, $1.8 \times 1.0 \mathrm{~mm}$. Petals translucent yellow, suffused with rosy-purple at the adaxial side on the first third towards the base, shortly pubescent, one veined, narrowly ovate, the first third reflexed, and the final third incurved, long-acuminate, $1.5 \times 0.3 \mathrm{~mm}$. Lip dark purple with a straw-colored, elliptical mark at the adaxial surface, ovate, thick, fleshy, densely covered with papillae, the adaxial surface: concave, with thick margins, the abaxial surface: concave and centrally raised, the base with a round glenion, the apex acute ( $1 \mathrm{~mm}$ long), thick, abruptly inflexed in a 90 degree angle, laterally compressed forming a marked edge, $2 \times 1 \mathrm{~mm}$; fixed to the column-foot. Column yellow, stout, semiterete, $0.5 \times 0.6 \mathrm{~mm}$, the stigma bilobate, the foot rudimentary. Pollinia not observed. Fruit a capsule, not observed.

Eтymology: Platystele cedriensis is named after Los Cedros Reserve where it was discovered.

OtHeR STUDIED MATERIaL: Flowers in alcohol from wild and cultivated plants of the botanical garden of Quito collected at the type locality at Los Cedros Reserve $L B$ 3133, LB 3134, LB 3135, LB 3136, LB 3137, LB 3138, LB 3139, LB 3140, LB 3141, LB 3142 (paratype, QCNE).

Platystele decouxii Baquero \& G.Verkovitch, sp. nov.

TYPE: Ecuador. Imbabura, "Los Cedros" Reserve, $0^{\circ} 18^{\prime} 35.62^{\prime \prime} \mathrm{N}, 78^{\circ} 46^{\prime} 47.01^{\prime \prime} \mathrm{W}, 1200 \mathrm{~m}, 5 / 11 / 2017$, Luis Baquero 3111 (Holotype, QCNE). Figs. 2, 5.

Diagnosis: Similar to Platystele pubescens, $P$. ximenae, and $P$. adelphe from which it all differs on the cordate lip with involute margins with a heartshaped depression in the disc (Fig. 5B) versus, the transversely ovate-cordate lip with a disc slightly channeled in P. pubescens, the transversely cordate lip with a transverse bilobed, cellular-glandular callus in the disc in $P$. ximenae and a transversely cordate lip with a slightly concave, featureless disc in $P$. adelphe.

Plant small, epiphytic, caespitose, erect, up to 25 $\mathrm{mm}$ tall. Roots basal, slender, $0.8 \mathrm{~mm}$ in diameter. Ramicauls terete, very short enclosed by two or three ribbed, imbricating sheaths. Leaf erect, coriaceous, spatulate elongated, $16-23 \mathrm{~mm}$ long, including a petiole 5-7 mm long, 4.0-4.8 $\mathrm{mm}$ wide, retuse apex. Inflorescence weak, suberect, loose, distichous, flexuous, solitary to successively several-flowered raceme, raceme, up to $50 \mathrm{~mm}$ long; borne by a slender ( $0.40 \mathrm{~mm}$ in width) peduncle $30 \mathrm{~mm}$ long arising from the ramicaul; pedicels 1.6-2.6 mm long. Ovary 

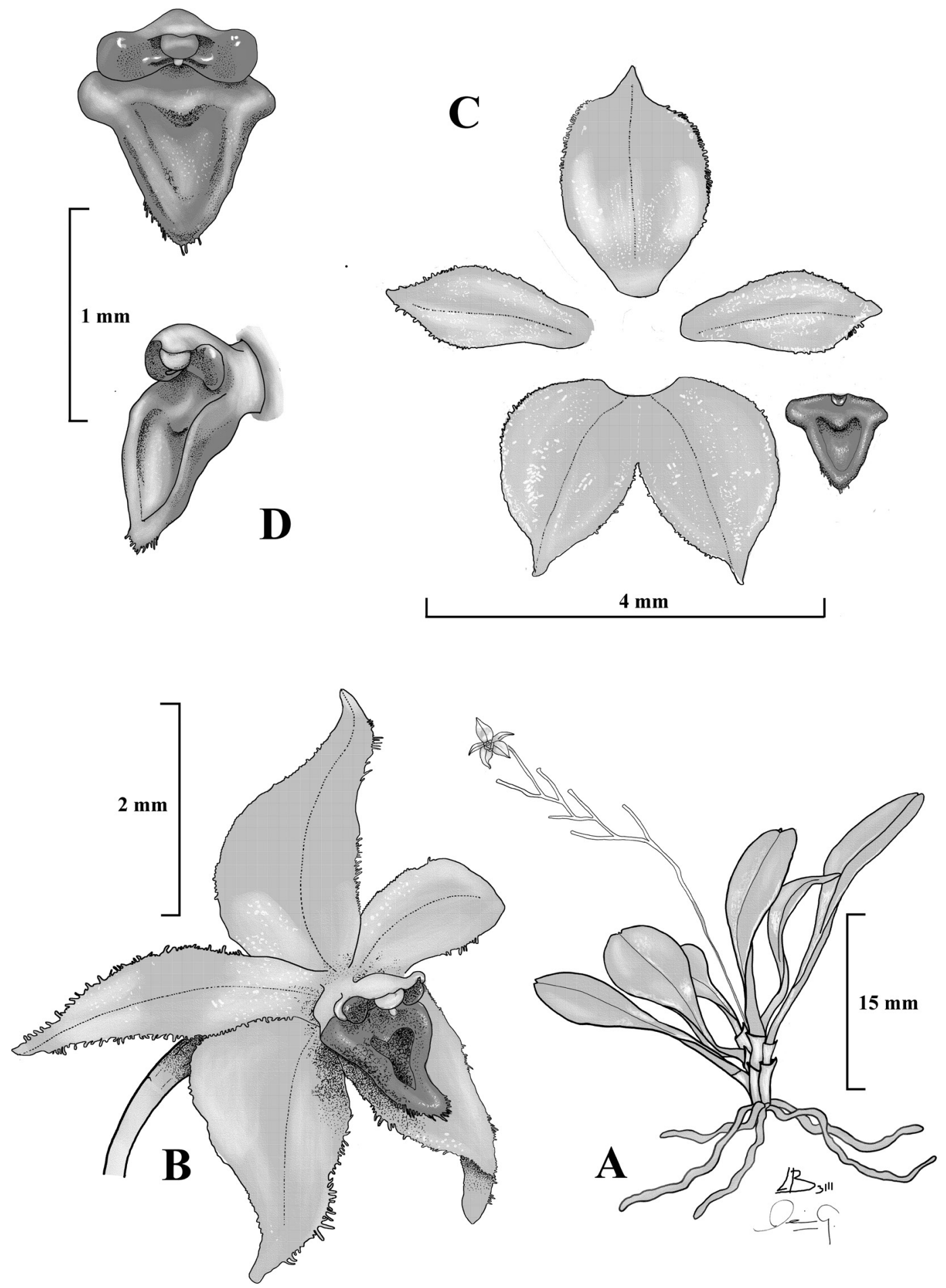

Figure 2. Platystele decouxii Baquero \& G.Verkovitch. A. Habit. B. 3/4 view of the flower. C. Disected perianth. D. Frontal and $3 / 4$ view of column and lip. Drawing by Denisse Galarza-Verkovitch and Luis E. Baquero from holotype. 

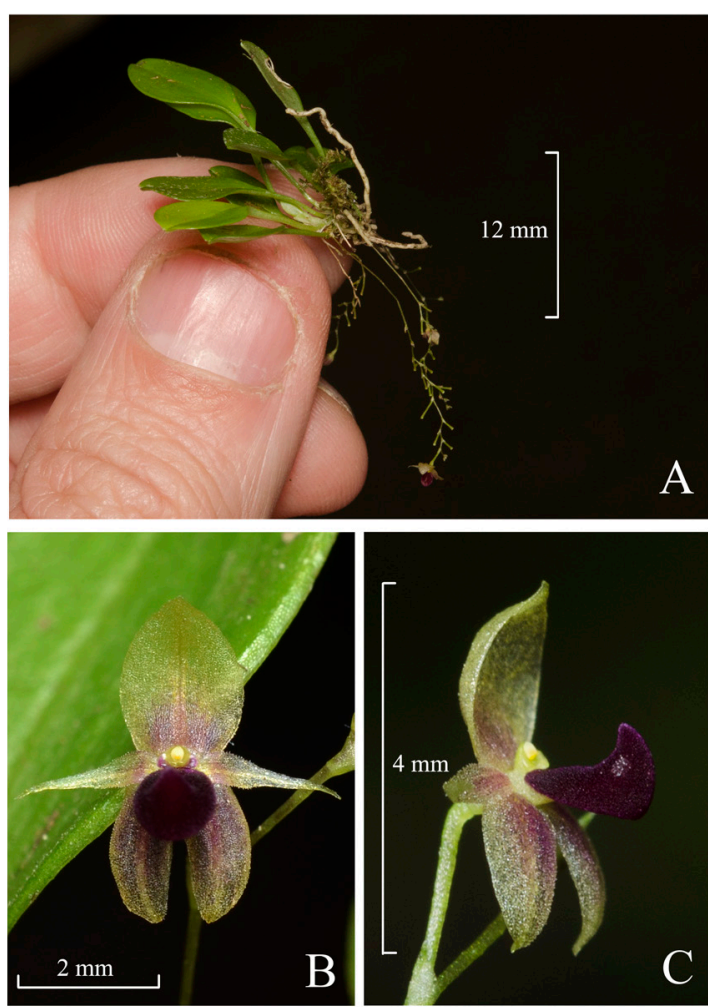

Figure 3. Platystele cedriensis Baquero \& G.Verkovitch. A

Plant and habit. B. Frontal view of the flower. C. $3 / 4$ view of the flower. Photos by Luis E. Baquero.

smooth, short, 6 ridged, $0.45 \times 0.30 \mathrm{~mm}$. Sepals translucent yellowish-green to yellow suffused with rosy-purple, at the adaxial side, on the first third towards the base and following the vein line, short glandular to glandular; dorsal sepal one veined, broadly elliptical and concave, $2.3 \times 1.6 \mathrm{~mm}$, with an acuminate apex; lateral sepals free, broadly elliptical, oblique, slightly convex, with and an acuminate apex, one veined, $2.6 \times 1.6 \mathrm{~mm}$. Petals translucent yellow, suffused with rosy-purple at the adaxial side on the first half towards the base, short glandular, one veined, obovate, slightly incurved, apex acuminate, $2.2 \times$ $1.0 \mathrm{~mm}$. Lip cordate, yellow, orange or rosy-colored, glandular, obovate, acute with thickened and involute lateral margins, a heart-shaped depression in the center of the blade, small glenion at the base, apex acute, $1.3 \times 0.9$. Column yellow, stout, semiterete, $0.5 \times 0.4$. Pollinia not observed. Fruit a capsule, not observed.
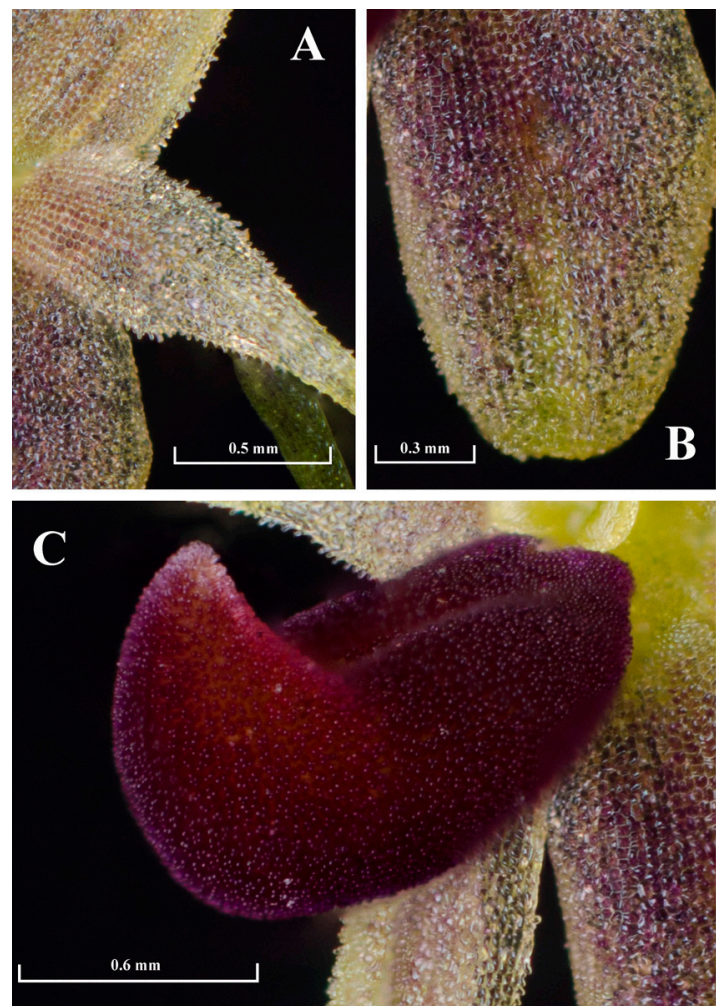

Figure 4. Platystele cedriensis Baquero \& G.Verkovitch. A.

Shortly pubescent petals. B. Shortly glandular sepals. C. Detail of the lip with papillae and the abruptly inflexed 90 degrees angle apex. 40x magnification photo stalking by Luis E. Baquero.

Etymology: Named after José DeCoux, creator and heroic guardian of Los Cedros Reserve, who has dedicated most of his life to conservation of Ecuadorian cloud forests.

Other STUDied MATERiaL: Flowers in alcohol from wild and cultivated plants of the botanical garden of Quito collected at the type locality, Los Cedros Reserve, $L B$ 3143, LB 3144 (paratype, QCNE).

\section{Additional New ReCORDS FOR PLATYSTELE SPECIES From Los Cedros Reserve}

Platystele gaileana Luer \& Endara and $P$. caudatisepala (C.Schweinf.) Garay were the only previously known species of the genus from Los Cedros Reserve. The research team of UDLA-JBQ have previously added Platystele alucitae Luer, $P$. pubescens Luer, P. sp. aff. pamelae Baquero \& Zuchan 


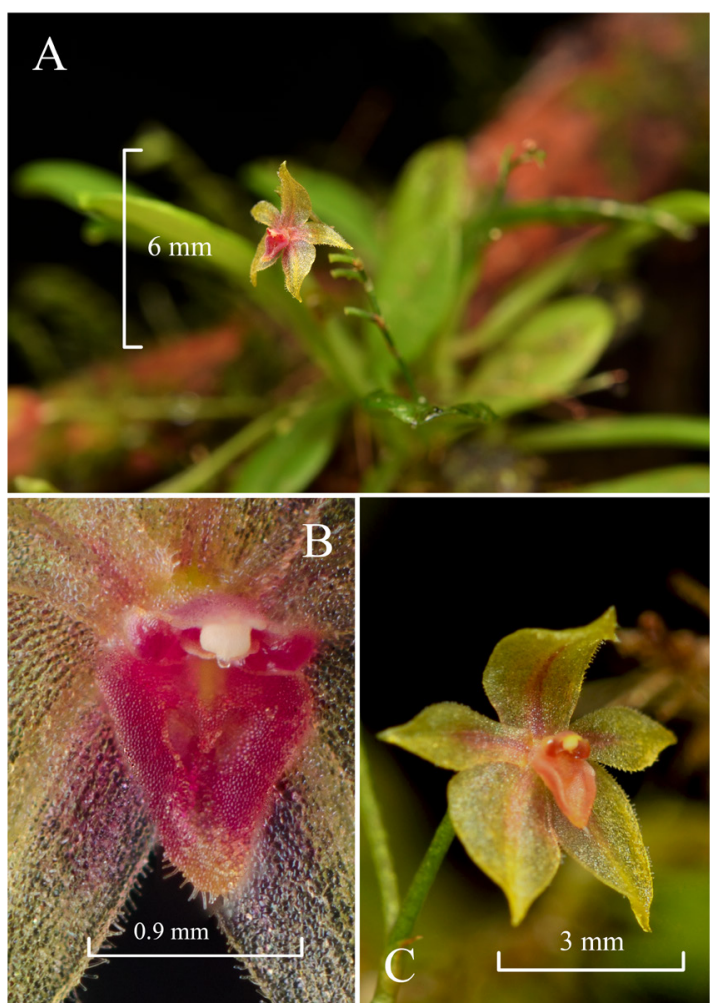

Figure 5. Platystele decouxii Baquero \& G.Verkovitch. A.

Habit and flower of dark lip form. B. Close-up of the lip where the heart-shaped depression is shown. C. Flower close-up of xanthic form. Photos by Luis E. Baquero.

(Fig. 6), in addition to the two new species described here. Interestingly, although Los Cedros has been explored for orchids in the past these five species have remained unnoticed until now. Spectacular species like Brachionidium ingramii Luer \& Dalström or Dracula lafleurii Luer \& Dalström can easily distract attention from tiny Platystele species from Los Cedros (Luer 1990, 1993,1996, Baquero \& Zuchan 2017).

The form of P. caudatisepala from Los Cedros is remarkable, with huge flowers for the genus (and even big for $P$. caudatisepala), with an intense pink color. Platystele cf. pamelae resembles the type of P. pamelae, first found in Carchi. The flowers of the form found in Los Cedros nevertheless shows a different shaped lip (pyriform with a round depression) compared with the lip of the flowers from the Carchi population of P. pamelae (oblong with a linear depression). Further studies are needed to confirm if the Los Cedros form is a different species or a geographic variation of $P$. pamelae. Platystele alucitae was also found in Los Cedros, bearing flowers that are similar to those from populations from El Oro province further south (Fig. 6). Finally, Platystele pubescens was also found in Los Cedros at 2000 m elevation where Dracula chiroptera Luer \& Malo, Scaphosepalum decorum Luer \& R.Escobar, Lepanthes manabina Dodson and other species of orchids were seen growing sympatrically (Luer 1988, 1990, 1993, 1996). A single plant of what appeared to be a fourth species of Platystele was found growing in Los Cedros around $1600 \mathrm{~m}$, but the only flower present was damaged, precluding confident identification.

Certainly, the main surprise concerning Platystele was the two new species growing, apparently neither uncommon at the Reserve.

Platystele cedriensis (Figs. 1, 3 and 4).- This species was found growing in lower elevations, around 1200 meters, and was locally abundant. The forest where it was found looked less pristine than high elevation forests of the Reserve, and seemed to be recovering from a woodcutting from the past. This species belongs to a group of species of Platystele characterized by plants with large leaves (sometimes spatulate) compared to the tiny flowers, which always present thick lips with an incurved and acute apex. Platystele fimbriata Luer \& Hirtz, P. rhinocera Luer, P. resimula Luer \& Hirtz, $P$. spatullata Luer and $P$. tobarii Luer all belong to this group of species. Three species belonging to this group, including $P$. fimbriata, $P$. tobarii and the new $P$. cedriensis, possess three-veined dorsal sepals. Besides these three species, no other species of Platystele have dorsal sepals with more than a single vein. Platystele tobarii has a "rose-thorn" shaped lip with erect inflorescences, and P. fimbriata has densely pubescent, broad flowers, also from erect inflorescences. Platystele cedriensis differs in possessing either horizontal or descending inflorescences and a lip with 90 degree angle inflexed apex instead of an incurved apex in the species mentioned above. Superficially, the most similar species to $P$. cedriensis might be $P$. rhinocera Nevertheless, the three-veined sepal and the shortly pubescent petals easily distinguish $P$. cedriensis from $P$. rhinocera but, also, the sepals covered by a cellularglandular texture compared to the glabrous sepals in $P$. rhinocera (Luer 1990, Luer 2004, Luer 2006). 

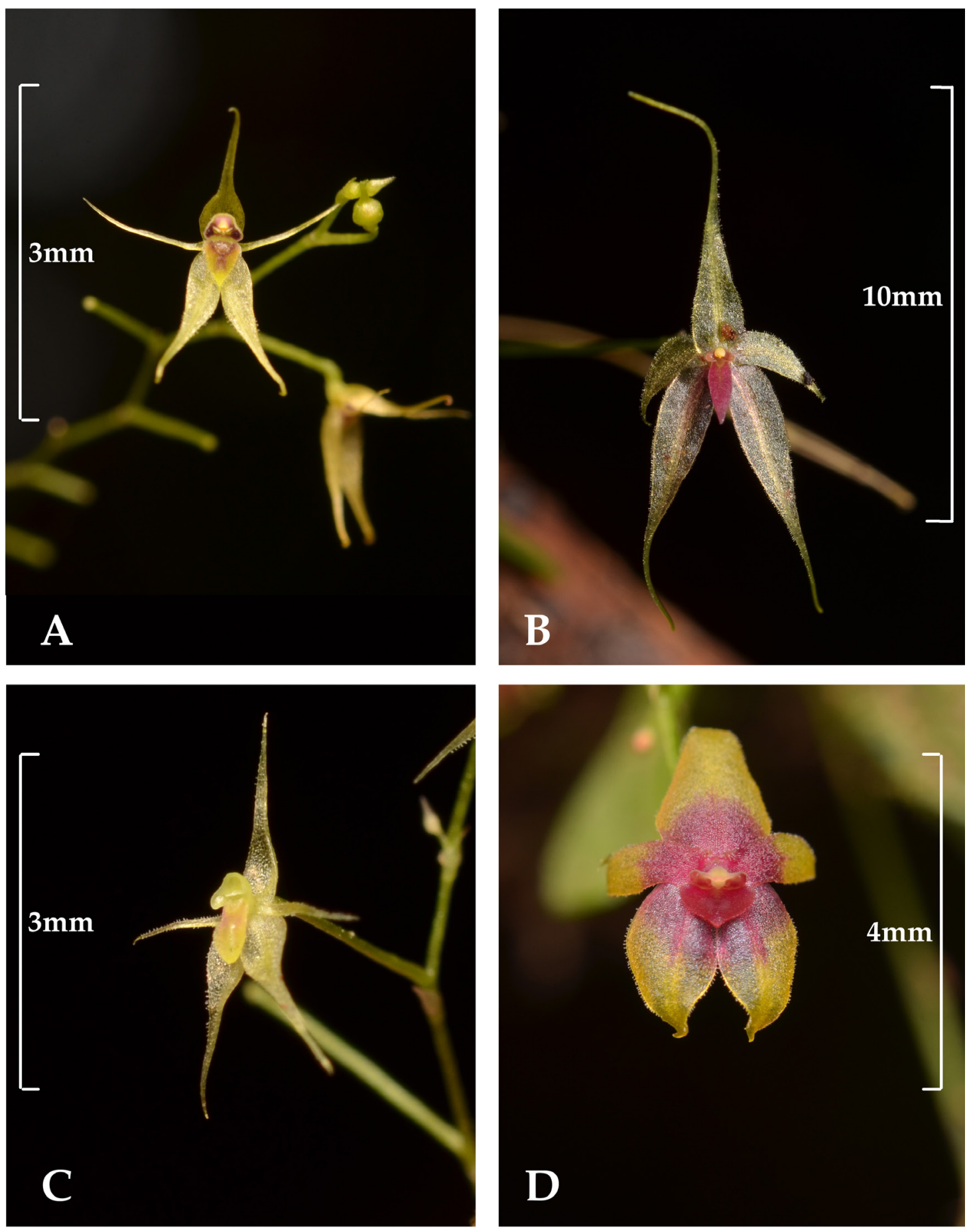

FiguRe 6. Differents Platystele species of Los Cedros Reserve. A. Platystele alucitae Luer. B. Platystele caudatisepala (C.Schweinf.) Garay. C. Platystele sp. (aff. P. pamelae Baquero \& Zuchan). D. Platystele pubescens Luer. Photos in situ by Luis E. Baquero. 
Platystele decouxii (Figs. 2 and 5).- This species was discovered close to Los Cedros Research House and presented two forms; a xanthic flowered form and a pigmented one (Fig. 5). The species was found growing around 1500 meters in elevation and two populations were found. Based on the broad shape of the sepals and petals, both covered with dense pubescence, a broad lip, and an incurved column, this species could be related to Platystele pubescens Luer, P. ximenae Luer \& Hirtz and $P$. adelphe Luer \& Hirtz (Luer 1990, 1991, 1994). Nevetheless, P. pubescens has a transversely ovate-cordate lip with the disc slightly channeled, $P$. ximenae and $P$. adelphe both have transversely cordate lips with cellular glandular callus, in the first, and slightly concave and featureless, in the second, which compared to the cordate lip with a heart-shaped depression in the disc in $P$. decouxii immediately distinguishes it from the three mentioned species. Other features like the involute margins and obtuse apex of the lip add differences to $P$. decouxii compared to similar species. At the Quito Botanical Garden further culture of additional plants from the original collection maintained all their identifying morphology, including the lip (Fig. 5).

Ecological notes.- As previously described, these two species come from different elevations and possibly represent different extremes from a highly orchid diverse "floor". The elevation where Platystele decouxii was discovered is also characterized by the presence of other orchid species such as Platystele caudatisepala, Lepanthes unijuga Luer \& Dalström, Lepanthes tortuosa Luer \& Hirtz -reported here for the first time from Los Cedros-, Scaphosepalum dodsonii Luer, Dracula lafleurii, Brachionidium ingramii and Masdevallia ximenae Luer \& Hirtz. The ecosystem is classified as an intermediate elevation cloud forest, where some endemic species seem to be unique from this orchid-diverse floor like $B$. ingramii or $L$. unijuga. Some species like $S$. dodsonii, although not endemic (as it is also known to occur further South), is uncharacteristically abundant in this elevation, though decreases in abundance at higher elevations where $S$. digitale becomes fairly abundant (Luer 1988, 1991, 1993). Platystele cedriensis on the other hand grows in the lowest elevation range of the same orchid-diverse "floor". Certain orchid species were common at this elevation, yet uncommon at higher elevations, like Lepanthes tortuosa or L. ricina. Platystele cedriensis seems to be locally abundant, though appears to be restricted in distribution.

The biggest concern for both species described here, as well as all orchid species from Los Cedros Reserve, is the threat of mining. Official mining leases have been issued to foreign companies around Ecuador. In the case of Los Cedros, a mining concession that has been approved threatens a large area of the reserve, and placing at risk the future persistence of orchid species from Los Cedros Reserve, including the two new species described here (Roy et al. 2018).

AcKNOWLEDGEMENTS. We acknowledge Universidad de Las Américas (UDLA) for funding research on orchids in Ecuador. The Ministerio del Ambiente del Ecuador is acknowledged for issuing the Environmental Research Permit No. 008-2016-IC-FLO-DNB/MA. We also thank $\mathrm{J}$. Yeager for the revision of this manuscript and language corrections done here. The authors are most grateful to J. DeCoux, to whom this paper is dedicated, for his commitment on the conservation of the forests from Los Cedros Reserve. Finally, we are grateful to the Editor and the anonymous reviewers for suggestions on the manuscript.

\section{LiTERATURE CITED}

Baquero, L. E. \& Zuchan, K. (2017). Platystele pamelae (Orchidaceae: Pleurothallidinae) a new species from Ecuador. Lankesteriana, 17(2), 245-250.

Dodson, C. H. (2003). Native Ecuadorian Orchids IV: Oncidium - Restrepiopsis. Quito, Ecuador: Imprenta Mariscal.

Dodson, C. H. (2004). Native Ecuadorian Orchids V: Rodriguezia-Zygosepalum. Quito, Ecuador: Imprenta Mariscal.

Jørgensen, P. M. \& Leon-Yanez, S. (Eds.). (1999). Catálogo de las plantas vasculares del Ecuador, Volumen 75. St. Louis: Missouri Botanical Garden Press.

Luer, C. A. (1988). Icones Pleurothallidinarum V. Systematics of Dresslerella and Scaphosepalum (Orchidaceae). Monogrpahs in Systematic Botany from the Missouri Botanical Garden, 26, 53-54.

Luer, C. A. (1990). Icones Pleurothallidinarum VII. Systematics of Platystele (Orchidaceae). Monographs in Systematic Botany from the Missouri Botanical Garden, 38, 1-132.

Luer, C. A. (1991). Eight new Masdevallia species. Novon, 1(4), 171-174.

Luer, C. A. (1993). Icones Pleurothallidinarum X. 
Systematics of Dracula (Orchidaceae). Monographs in Systematic Botany from the Missouri Botanical Garden, 46, 120-121, 142-143.

Luer, C. A. (1994). Icones Pleurothallidinarum XI. Systematics of Lepanthes, subgenus Brachycladium, and Pleurothallis, subgenus Aenigma, subgenus Elongatia, subgenus Kraenzlinella; Addenda to Dracula, Lepanthopsis, Myoxanthus, Platystele, Porroglossum, and Trisetella. Monographs in Systematic Botany from the Missouri Botanical Garden, 52, 121.

Luer, C. A. (1996). Icones Pleurothallidinarum XIV. Systematics of Draconanthes, Lepanthes subgen. Marsipanthes and subgen. Lepanthes of Ecuador (Orchidaceae). Monographs in Systematic Botany from the Missouri Botanical Garden, 61, 114, 221.

Luer, C.A. (2004). Icones Pleurothallidinarum XXVI. Pleurothallis subgen. Acianthera and three allied subgenera; A Second Century of New Species of
Stelis of Ecuador; Epibator, Ophidion, Zootrophion (Orchidaceae). Monographs in Systematic Botany from the Missouri Botanical Garden, 95, 236, 239, 241, 242.

Luer, C. A. (2006). Icones Pleurothallidinarum XXVIII. Reconsideration of Masdevallia, and the Systematics of Specklinia and Vegetatively Similar Genera (Orchidaceae). Monographs in Systematic Botany from the Missouri Botanical Garden, 105, 258.

Neill, D. A. \& Ulloa, C. U. (2011). Adiciones a la flora del Ecuador: segundo suplemento: 2005-2010 (p.126). Quito, Ecuador: Fundación Jatun Sacha.

Roy, B. A., Zorrilla, M., Endara, L., Thomas, D. C., Vandegrift, R., Rubenstein, J. M., Policha, T., Rios-Touma, B. \& Read, M. (2018). New Mining Concessions Could Severely Decrease Biodiversity and Ecosystem Services in Ecuador. Tropical Conservation Science, 11, 1-20. 
